\title{
Static bending of glulam beams manufactured with rubber wood and epoxy adhesive
}

Douglas Lamounier Faria ${ }^{1}$, Thamirys Andrade Lopes ${ }^{2}$,

Mário Vanoli Scatolino ${ }^{1}$, Julio Soriano ${ }^{3}$, Lourival Marin Mendes ${ }^{1}$, José Benedito Guimarães Júnior ${ }^{4}$

\author{
${ }^{1}$ Federal University of Lavras, Department of Forest Science, POB 3037, CEP: 37200-000, Lavras, Minas Gerais, MG, \\ Brasil. \\ ${ }^{2}$ Federal University of Viçosa, Av. Peter Henry Rolfs, POB 22, CEP: 36570-000, Viçosa, Minas Gerais, MG, Brasil. \\ ${ }^{3}$ Agricultural Engineering - University of Campinas - UNICAMP, Av. Candido Rondon, CEP: 13083-875, Campinas, \\ São Paulo, SP, Brasil. \\ ${ }^{4}$ Federal University of Lavras, Department of Engineering, POB 3037, CEP: 37200-000, Lavras, MG, Brasil. \\ e-mail: douglas.lamounier@yahoo.com,mario_paraiso@hotmail.com, lourival@dcf.ufla.br, thamiryscpo@hotmail.com, \\ julio.soriano@feagri.unicamp.br, jose.guimaraes@deg.ufla.br
}

\begin{abstract}
The aim of this study was to evaluate the properties of Hevea brasiliensis wood wastes for production structural pieces of glued laminated (glulam) timber. Three trees with age close to 25 years and diameter at breast height (DBH) higher than $500 \mathrm{~mm}$ were obtained. The basic density of the wood were quantified, as well as the stiffness and the strength in static bending, shear strength and parallel compression to grain and hygroscopic equilibrium moisture. The beams of glulam were evaluated according to the modulus of elasticity (MOE), modulus of rupture (MOR) and delamination. Due to the bending properties MOR (75.14 MPa) and MOE (8166.79 MPa), as well as the shear strength (12.29 MPa) obtained, was concluded by the suitability of the rubber wood for the production of glulam beams. The composite beams presented values of MOR (75.14 MPa) and MOE (8166.79 MPa) compatible with species traditionally used in the production of glulam beams. The adhesive bond quality was verified by the delamination test, presenting delamination of $4.95 \%$, indicating its use for internal and external environments.
\end{abstract}

Keywords: Composite; Wood; Bond resistance; Static bending.

\section{INTRODUCTION}

Rubber tree (Hevea brasiliensis) is economically exploited to produce latex with a good quality and high rubber content. The latex extraction begins in the sixth year of planting, but the production only reaches its maximum level around the tenth year and remains about 30 years, approximately [1]. On the other hand, the Hevea brasiliensis wood shows potential for structural use after the latex extraction period [2]. Its natural dispersion is fixed into the limits of the Brazilian Amazon, but has shown great adaptability to several environments, such as the Southeast region, Central West, Bahia, and more recently, in the western part of the State of Paraná. According to the annual report of the Brazilian Tree Industry IBÁ [3] the planted area with rubber trees in Brazil in 2016 reached 229,964 ha, which implies in increase of 905 ha when compared to 2015, being the third specie most planted in the country, followed by eucalyptus and pine. When the latex extraction of the tree is no longer economically feasible, which characterizes the end of its productive cycle, the trees are removed, to reformulate the planting. In Brazil, the wood obtained at the end of the latex production cycle is exclusively used for energy purposes [4]. Current studies have focused on the use of this wood in furniture industries, sawn wood and wood-based panels, among others. This focus aims to develop new products to increase the value of Hevea brasiliensis in the end of the latex production cycle, creating an additional income option for Brazilian latex producers [1].

The production of glulam timber has the advantage of using laminations sawn from small and fast-growing trees [5] and, in general, is employed a wood with low density and modulus elasticity. However, the potential of rubber wood for production of structural pieces is still understudied. Glulam is considered a structural product formed by the association of selected wood pieces arranged so that the fibers are parallel and bonded with waterproof adhesives under pressure varying from 0.7 to $1.5 \mathrm{MPa}[6]$. 
The possibility of forming arches and structural components with curvatures and large span has boosted the popularity of glulam structures both in Europe and in the US [7]. In recent years, the glulam structures have been popularly applied in historic building, landscape architecture, etc., throughout the world due to the advantages in energy conservation, environmental protection, excellent structural performance, etc. Regarding the gluing of the beams, the literature reports the use of several adhesives such as resorcinol resin [5] and polyurethane [8]. It is known that the behavior of the adhesive-bonded joints is significantly governed by the bond between the adhesive and the adherents. Harvey and Ansell [9] conducted pull-out tests on timber joints to investigate the effects of surface treatment, bonded length, bond-line thickness, moisture content and adhesive type on the joint behavior. As the glulam beams are commonly used in external applications in which the beams are exposed to varying moisture conditions and temperatures, the choice of the suitable adhesive is extremely important.

In this context, the aim of this study was to evaluate the flexural performance of the glued laminated wood produced with Hevea brasiliensis, taking into account the mechanical and physical properties of this type of wood, particularly the clone $\mathrm{Pb} 235$.

\section{MATERIAL AND METHODS}

\subsection{Obtainment and preparation of the rubber wood}

Three specimens of rubber tree (Hevea brasiliensis), clone $\mathrm{Pb} 235$, with 25 years of age and DBH higher than $500 \mathrm{~mm}$ were collected from the campus of Federal University of Lavras (UFLA), located in Lavras, (height: $900 \mathrm{~m}$; latitude: 21 ${ }^{\circ} 14^{\prime}$ 'S and longitude: $45^{\circ} 00^{\prime} \mathrm{W}$ ) State of Minas Gerais, Brazil. From each tree, logs were obtained from the basal area (length close to $1.30 \mathrm{~m}$ ), which were sawn in planks. The planks were conditioned in an environment with temperature of $22 \pm 2{ }^{\circ} \mathrm{C}$ and relative humidity $65 \pm 5 \%$. Posteriorly, the samples were obtained with the dimensions according to established standards (Table 1). For each property test 12 specimens were used in accordance with the requirements of NBR 7190 [10] for minimum characterization of the little-known species strength.

Table 1: Specimens for physical and mechanical tests of rubber wood, dimensions standardized according to NBR 7190 [10].

\begin{tabular}{l|c}
\hline Property & Dimensions $(\mathbf{m m})$ \\
\hline MOE and MOR in static bending & $50 \times 50 \times 1150$ \\
\hline Compressive strength parallel to grain & $50 \times 50 \times 150$ \\
\hline Shear strength parallel to the grain & $50 \times 50 \times 64$ \\
\hline Moisture content & $20 \times 30 \times 50$ \\
\hline Basic density & \\
\hline
\end{tabular}

Where: MOE - Modulus of Elasticity; MOR - Modulus of rupture.

\subsection{Production of the glulam beams}

From the central planks were obtained laminations with cross-section of $25 \times 70 \mathrm{~mm}$ and length of $1200 \mathrm{~mm}$ which were dried until reach moisture content of $12 \%$. Posteriorly, the faces were planed to reach final dimensions of $20 \times 60 \times 1200$ $\mathrm{mm}$. The pieces were classified by the impulse excitation technique with the Sonelastic machine (Sonelastic, ATCP, Brazil). For production of the glulam (Table 2) the laminations were classified according to the MOE value, being the pieces with higher values applied as faces, and the pieces with lower values as the core. Five glulam beams were produced with dimensions of $20 \mathrm{~mm} \times 60 \mathrm{~mm} \times 1200 \mathrm{~mm}$ using 3 laminations, glued with adhesive composed by epoxy resin (TEKBOND, Brazil), bi-component, in proportion 1:1 of the resin (Bisfenol) to the catalyst (Trietilenotetramina) (Table 2). 
Table 2: Parameters for the production of the glulam beams.

\begin{tabular}{l|c|c}
\hline \multirow{2}{*}{ Parameter } & \multicolumn{2}{|c}{ Value } \\
\hline \multirow{2}{*}{ Apparent viscosity $\left(25^{\circ} \mathrm{C}\right)$} & Resin: $30000-50000 \mathrm{cP}$ & \multirow{2}{*}{ Proportion $1: 1$} \\
\cline { 2 - 3 } $\mathrm{pH}$ & Catalyst: $20000-35000 \mathrm{cP}$ & \\
\hline Grammage & 11 & \\
\hline Pressure and clamping time & $350 \mathrm{~g} \cdot \mathrm{m}^{-2}$ & \\
\hline
\end{tabular}

After pressing, the beams were conditioned in an environment with temperature of $22 \pm 2{ }^{\circ} \mathrm{C}$ and relative humidity 65 $\pm 5 \%$ until reach the moisture content of $12 \%$. The static bending test were performed according to the American Society for Testing and Materials D198 [11], for determination of MOE and MOR.

To evaluate the delamination of specimens extracted from glued laminated beams, six specimens measuring $7.5 \mathrm{x}$ $6.0 \times 6.0 \mathrm{~cm}$ (length, width and thickness) were drawn parallel to the fibers, using the methodology described by Lestari et al. [12]. The test was performed by allowing the samples to remain immersed for 6 hours in water, 18 hours in a forced air oven at $40 \pm 3{ }^{\circ} \mathrm{C}, 4$ hours under boiling at $100{ }^{\circ} \mathrm{C}, 1$ hour immersion in water at room temperature and finally 18 hours in an oven at $70 \pm 3{ }^{\circ} \mathrm{C}$. After the test, the behavior of the glued laminated beams exposed to the exterior was evaluated, evaluating the percentage of delamination, which was obtained on the two top faces of the specimens. In order to verify the percentage, the length of each glue line in which delamination occurred was obtained, and this was divided by the total length of the glue line, according to equation 1 .

$$
\text { Del }=(\text { DelLength/TotalLength }) * 100
$$

On what:

Del $=$ Delamination $(\%)$;

DelLength $=$ Length at which delamination occurred $(\mathrm{mm})$;

TotalLength $=$ Total length of glue line $(\mathrm{mm})$.

\section{RESULTS}

\subsection{Physical characterization of rubber wood}

The mean values for moisture content were $11.29 \pm 0.53 \%$, consistent with the equilibrium moisture of the wood after the drying process, being close to $12 \%$. By the results of basic density equal to $0.54 \mathrm{~g} . \mathrm{cm}^{-3}$ and according to Mendes et al. [13], the Hevea brasiliensis wood can be classified as medium to low density wood.

\subsection{Mechanical characterization of the rubber wood}

The mean values for compressive strength and shear stregnth were $56.28 \pm 4.20 \mathrm{MPa}$ and $10.89 \pm 0.99 \mathrm{MPa}$. Regarding the mean values for MOR and MOE of the rubber wood pieces were $61.59 \pm 19.57$ and $6372.09 \pm 2922.52 \mathrm{MPa}$, respectively.

\subsection{Static bending of glulam beams}

The results of strength (MOR) $(75.14 \pm 5.41 \mathrm{MPa})$ and stiffness (MOE) $(8166.79 \pm 1856.34 \mathrm{MPa})$ properties for glulam beams produced with rubber wood and obtained by bending at three points were higher than the values obtained to the rubber wood (61.59 and $6372 \mathrm{MPa}$ for MOR and MOE, respectively). The glulam products are stronger and stiffer than standardized timber products [14].

The predominant mode of failure is the tension failure in laminated beams with the crack starting from bottom layer and spreading on the cross-section height, with concomitant crushing of the compressed fibers (top) of the beam (Figure 1). In this failure process, by the static conditions with three-point bending, in the mid-span of the beam was also observed the formation of cracks associated to shear, which propagated according to the grain orientation. 


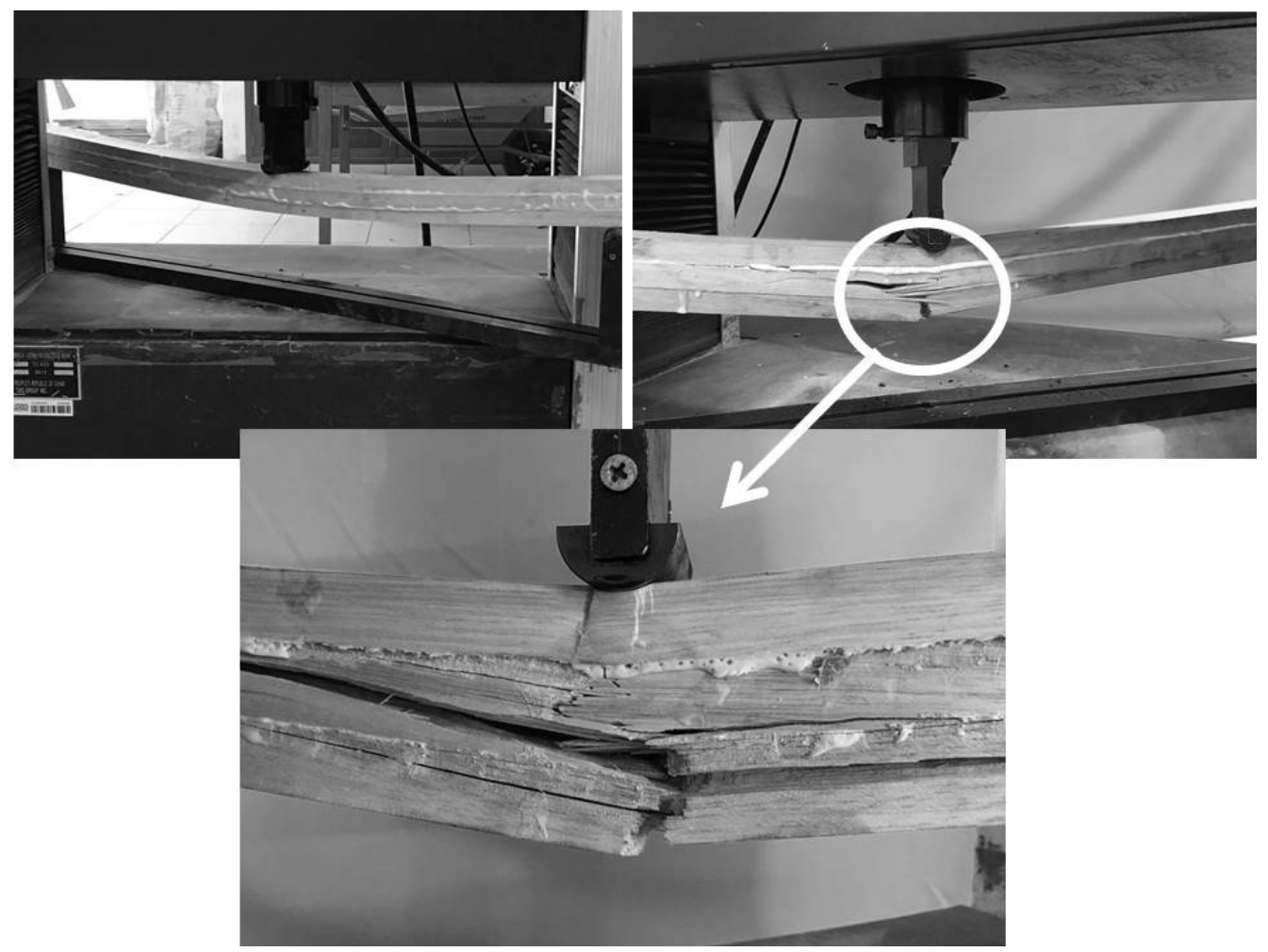

Figure 1: Typical failure of glulam beam submitted to static bending.

Two different types of fracture may occur as expected within the glulam: intralaminar fracture or interlaminar fracture. Intralaminar fracture takes place within individual laminae, which is inherently the fracture of solid wood, while interlaminar fracture occurs at the interface of two adjacent laminae [15]. For wood with strongly anisotropic fibers, the fracture tends to occur along the fiber direction. Wood is an intrinsically anisotropic material, produced by the specific deposition of anatomical elements during the life of a tree. Three axes, perpendicular to each other are used to define this structure; a longitudinal axis oriented parallel to the tree stem (L), a radial axis perpendicular to the growth rings and a tangential axis parallel to the growth rings (T). The different orientations (and hence properties) of wood have been utilized for construction purposes. For example, early ship building techniques tended to use radially split planks, whereas later methods used tangentially sawn planks.

\subsection{Delamination of glulam beams}

In relation to the test of delamination of the test pieces of glued laminated beams, it was noted by visual verification of the state of the glue lines that the specimens did not present delamination slits; it was verified that the percentage of delamination was equal to zero.

\section{DISCUSSION}

\subsection{Physical characterization of rubber wood}

The effects of the wood moisture content on the adhesive bond performance starts with the amount and absorption rate of the adhesive liquid part. Therefore the lower is the moisture content of the wood, higher is the absorption and solidification rate [16].

Each type of adhesive requires a specific range of moisture content of the wood, in order to promote an adequate adhesion between the pieces of laminated wood. The epoxy adhesive presents better adhesion to the wood with moisture content close to $12 \%$ [17]. The satisfactory results for the mechanical properties can be explained by the good adhesion between adhesive and wood. The use of dried laminations is extremely important for the success of the glulam beams, since high moisture content damages the gluing process and produces checking and other drying defects [5]. The moisture 
content obtained in the present study was below $18 \%$, the maximum value recommended by the NBR 7190 [10]. Glulam is normally manufactured using lumber with the moisture content in the range 10-16\%. It generally comes with camber or upward deflection.

Density is generally known as good indicating property for many strength and elastic properties of timber, i.e. the higher the density, the higher the mechanical properties of wood. Iwakiri [16] emphasizes that the wood density has an inverse relationship with the porosity and the penetration action of adhesives on the woody structure. The use of a wood with medium density could be an alternative in order to overcome the mechanical deficiency related the wood properties and, at the same time, maintaining a reasonable porosity rate essential for the bonding process. Similar values were obtained by Iwakiri et al. [18] when studying the effect of particle treatment on the production of cement-wood panels of Hevea brasiliensis wood and obtaining mean values for basic density of $0.572 \mathrm{~g} . \mathrm{cm}^{-3}$.

\subsection{Mechanical characterization of the rubber wood}

Considering the values of the mechanical properties obtained by the tests [10], it is observed that the compressive strength parallel to grain presented the mean value of $56.28 \mathrm{MPa}$. This value is close to those presented in the literature, as shown by Leonello et al. [4] studying the Hevea brasiliensis wood aiming evaluate the wood quality and classify it structurally, obtained 49.83 MPa for MOR, values similar to those obtained by Majumdar et al. [19], which were between 46.3 and 50.0 MPa for Hevea brasiliensis wood with age of 25 years. When comparing the value of the compressive strength with values of other species studied in the literature, allows classify the Hevea brasiliensis wood in the group of species with mechanical quality and can be compatible with many woods traditionally applied in civil construction and the furniture industry.

The mean value for MOE obtained in the static bending was $6372.09 \mathrm{MPa}$, which was lower in comparison to the Leonello et al. [4], obtaining values for MOE between 9877 and $10107 \mathrm{MPa}$ for rubber wood. Majumdar et al. [19], for this same species of wood, obtained the values ranging between 8605 and $8973 \mathrm{MPa}$ for this stiffness property.

The shear strength of the wood is directly proportional to its density, but depends mainly on the direction which the stress is applied in relation to the growth rings [20]. The mean value obtained for the shear strength was $10.89 \mathrm{MPa}$, close to obtained by Santana et al. [21], which obtained mean values for shear strength ranging between 12.2 to $13.2 \mathrm{MPa}$ (dry condition) when evaluating different rubber clones.

For solid wood, it has been shown that the compression modulus of elasticity was generally lower than tension modulus of elasticity [22]. In the static bending, the bottom part of the sample is submitted to tension while the top part is under the action of compression. In fact, the material response along the fiber direction is quite different in tension and in compression. In tension, wood exhibits an elastic-brittle behavior whereas, in compression, it shows an elastic-plastic behavior with limited ductility, which causes premature brittle collapse before complete exhaustion of its plastic capacity [23]. It should be noted that NBR 7190 [10] standard uses the expression that considers the linear behavior in the compression and tension for calculation of the forces and strength in static bending. The bending moment causes normal stress in the cross section that leads to displacement forces able to move one part of the beam towards the other, resulting in shear stress parallel to grain and in the cross section $[24,25]$. This behavior occurs due to the differential of internal forces $(\mathrm{dx})$ in the equilibrium moment [M (bending moment) $+\mathrm{dM}$ (differential at the moment)], which cause horizontal movement of the parts (compressed and tensioned). Shear, and consequently tensions, are generated only when the bending moment is not constant.

The incorrect choice of the wood material for structural uses, concerning to strength properties can result in a structural damage, with consequently risks to human life [26]. Only wood species which have strength and rigidity properties consistent with those established in the NBR 7190 [10] standard can be used for structural purposes. Concerning the safety of the structure, as well as of people and equipments, must be satisfied one of the basic principles of the structural design, the named ultimate limit state. For this checking, ABNT NBR 7190 [10] establishes the specific safety coefficients that modify the characteristic values of the properties of the material and the specific loads.

The property of shear strength has a great importance in applying wood for the manufacture of glulam beams, since the shear consists of the fibers separation by a tension applied parallel to them. The ultimate limit state of the glulam, with respect to the shear parallel to grain, must be guaranteed by the ability of internal resistance to the sliding of one laminate to another, result of the bonding performance [5], as well as the shear strength of each laminates.

\subsection{Static bending of glulam beams}

The results obtained in this study were compatible with some values found in the literature. Iwakiri et al. [27] studying the characteristics of glulam beams manufactured with Tectona grandis wood and bonded with resorcinol-formaldehyde obtained MOR and MOE values in the range of 45 to $66 \mathrm{MPa}$ and, 12570 to $12893 \mathrm{MPa}$, respectively. Similar results were 
obtained by Segundinho et al. [28] evaluating glulam beams of Erisma uncinatum wood, which obtained MOR values ranging between 39.3 and 87.6 MPa and MOE ranging between 9687 and $12498 \mathrm{MPa}$ for beams produced with adhesives as resorcinol-formaldehyde and polyurethane.

In general, the analysis comparative of the static bending tests results shows the benefits of glulam of rubber wood, manufactured with epoxy adhesive, in relation to the solid beams. As reported by Bertoline et al. [29], the improving of structural performance of the glulam beam is expressed by the increase of bending strength and stiffness properties, that resulted equal to $22.00 \%$ and $28.17 \%$ for the MOR and MOE values, respectively. This improved performance reflects one of the main advantages of the wood composites, which is the possibility of obtains the required properties in a design. In this point of view, the higher MOE values indicate that the material is not easy to be deformed under bending load and, the higher MOR values indicate the superior capacity of the beam to support the bending load.

In evaluation of the mechanical strength of engineered or adhesive bonded wood products, generally wood failure is preferable since it indicates that the strength of resin or adhesive surpasses wood strength. Two types of potential mechanisms of wood failure are suggested by Flores and Friswell [30]. The first failure mechanism is associated to the longitudinal straining of the crystalline cellulose fraction. For each load step, the longitudinal tensile strain is computed in the crystalline fraction of the microscopic finite element. The second potential mechanism of failure is the accumulation of irreversible deformation in the amorphous fraction of cellulose. Wood, as a hygroscopic material, can absorb the applied adhesive by capillary forces, which can be a factor of adhesion failing at the wood-adhesive interface [31]. The performance of the bond line is closely related to the penetration of the adhesive, which is a complex phenomenon in wood, since the penetration can be influenced by different parameters such as the wood species, cutting direction, surface energy and glue viscosity. However, these factors do not seem to have affected the gluing of the glulam beams produced in this study. The results of MOR and MOE obtained for the rubber wood beams showed a potential of this wood for being applied as glulam pieces, since Hevea brasiliensis wood is currently a byproduct of latex production, being used mainly as biomass and charcoal. The results of the mechanical properties obtained for the glulam made with the Hevea brasiliensis wood were satisfactory in comparison to the values found in literature for woods as Tectona grandis and Erisma uncinatum Warm, which are common species used for production of glulam beams.

\subsection{Delamination of glulam beams}

Regarding the delamination test of the glued laminated specimens, it was observed, through the visual verification of the state of the glue lines, that the specimens had delamination slits; it was verified that the percentage of delamination was equal to $4.95 \%$. A similar result was observed by Fiorelli; Dias [32], whose authors obtained $6.64 \%$ delamination for pieces of glued laminated wood produced with epoxy adhesive.

The percentage of delamination observed in this study was lower than the maximum of $10 \%$ stipulated by European Standard EN 386 [33], and lower than the maximum allowed by Standard JAS 234 [34], which is $5 \%$.

\section{CONCLUSIONS}

The rubber wood, especially the clone $\mathrm{Pb} 235$, was characterized and used for the production of glulam beams. The moisture content of $11.29 \%$ provided good adhesion between the laminations, avoiding the delamination process. In relation to the value of compressive strength parallel to grain $(56.28 \mathrm{MPa})$, the studied wood is compatible with many woods traditionally used in civil construction and furniture industry. For the properties parallel to grain, the MOE (6372.09 MPa) and shear strength $(10.89 \mathrm{MPa})$ were consistent with values related by the literature, which becomes possible the use of Hevea brasiliensis wood for structural purposes such as the production of the glulam, since the species under study can be classified as C50 according to the NBR 7190 [10], compatible with other species traditionally used for glulam production, such as Eucalyptus grandis (C40) and Pinus oocarpa (C40). Finally, in relation to solid wood, this research showed that the rubber wood used to manufacture glulam timber improved significantly the bending performance of beams.

\section{ACKNOWLEDGEMENT}

The authors thank to Fundação de Amparo à Pesquisa do Estado de Minas Gerais - FAPEMIG. Coordenacão de Aperfeiçoamento de Pessoa de Nível Superior - CAPES. Conselho Nacional de Desenvolvimento Científico e Tecnológico - CNPq and PPGBiomat - Programa de Pós-Graduação em Engenharia de Biomateriais. 


\section{REFERENCES}

[1] MUZEL, S.D., GAVA, M., CORTEZ-BARBOSA, J. et al., "MDP panels manufactured with Hevea brasiliensis overlaid with bamboo foil of Phyllostachys edulis", Advanced Materials Research, v. 1088, pp. 686-689, 2015.

[2] EUFRADE JR, H.J., OHTO, J.M., SILVA, L. L. et al., "Potential of rubberwood (Hevea brasiliensis) for structural use after the period of latex extraction: a case study in Brazil”, Journal of Wood Science, v. 61, pp. 384-390, 2015.

[3] IBÁ - Instituto Brasileiro de Árvores. Relatório Anual de 2017.

[4] LEONELlO, E.C., BALLARIN, A.W., OHTO, J.M., et al., "Quality of Wood and Structural Classification of Hevea brasiliensis Clone GT 1”, Floresta e Ambiente, v. 19, n. 2, pp. 229-235, 2012.

[5] FOREST PRODUCTS LABORATORY. Wood handbook-Wood as an engineering material. General Technical Report FPL-GTR-190. Madison, WI: U.S. Department of Agriculture, Forest Service, Forest Products Laboratory, 2010.

[6] PFEIL, W., PFEIL, M., Estruturas de madeira, 6 ed., Rio de Janeiro, LTC, 2003.

[7] TELES, R.F., DEL MENEZZI, C.H.S., SOUZA, M.R. et al., "Effect of nondestructive testing of laminations on the bending properties of glulam beams made from louro-vermelho (Sextonia rubra)", Cerne, v. 16, n. 1, pp. 77-85, 2010.

[8] SORIANO, J., PELLIS, B.P., MASCIA, N.T., "Mechanical performance of glued-laminated timber beams symmetrically reinforced with steel bars", Composite Structures, v. 150, pp. 200-207, 2016.

[9] HARVEY, K., ANSELL, M.P., "Improved timber connections using bonded-in GFRP rods". In: Proceedings of 6th WCTE: World Conference in Timber Engeneering, pp. 2-8, 2000.

[10] ASSOCIAÇÃO BRASILEIRA DE NORMAS TÉCNICAS. ABNT. NBR 7190: project of wooden structures. São Paulo, 1997.

[11] AMERICAN SOCIETY FOR TESTING AND MATERIALS. ASTM. D198: Static tests of timbers in structural sizes. Philadelphia, 1996.

[12] LESTARI, A.S.R.D., HADI, Y.S., HERMAWAN, D. et al., "Glulam Properties of Fast-growing Species Using Mahogany Tannin Adhesive”, BioResources, v. 10, n. 4, pp. 7419-7433, 2015.

[13] MENDES, L.M., SILVA, J.R.M., TRUGILHO, P.F. et al., "Longitudinal variation on wood density of Pinus oocarpa", Cerne, v. 5, n. 1, pp. 102-111, 1999.

[14] PORTEOUS, J., KERMANI, A., Structural timber design to Eurocode 5. Blackwell Publishing, 2007.

[15] VINCENT, Z.W., JOHN, D.G., KRISHNEEL, N., "Intralaminar and interlaminar fracture characterization in glued-laminated timber members using image analysis”, Engineering Fracture Mechanics, v. 82, pp. 73-84, 2012.

[16] IWAKIRI, S., Painéis de madeira reconstituída. FUPEF. Curitiba, 2005.

[17] GEMERT, D. V., BOSCH, V., "Structural restoration of wooden beams by means of epoxy resin", Materials and Structures/Matériaux et Construction, v. 20, pp. 165-170, 1987.

[18] IWAKIRI, S., TRIANOSKI, R., WEBER, A. M. et al., "Effects of particles treatments and cement accelerator admixture in the wood cement panel production", Floresta, v. 47, n. 3, pp. 289-296, 2017.

[19] MAJUMDAR, M.S.M., DAS, A.K., SHAMS, M.I. et al., "Effect of age and height position on physical and mechanical properties of rubber wood (Hevea brasiliensis) of Bangladesh", Bangladesh Journal of Scientific and Industrial Research, v. 49, n. 2, pp. 79-84, 2014.

[20] MASSAYUKI, M., MATOSKI, A., MAGAJEWSKI, C. et al., "Shear strength parallel of the wood fiber stress by punching - proposed test”, Revista Ingeniería de Construcción, v. 29, n. 1, pp. 46-60, 2014.

[21] SANTANA, M.A.E., EIRAS, K.M.M., PASTORE, T.C.M., "Wood evaluation of Hevea brasiliensis clones by technological characterization”, Brasil Florestal, v. 70, pp. 61-68, 2001.

[22] YADAMA, V., WOLCOTTA, M.P., SMITH, L.V., "Elastic properties of wood-strand composites with undulating strands", Composites Part A: Applied Science and Manufacturing, v. 37, pp. 385-392, 2006.

[23] GIUBILEO, C., Experimental and theoretical analysis of structural behavior of Ancient Timber Structures, Doctoral thesis, 2005.

[24] BEZAZI, A., SCARPA, F., "Mechanical behavior of conventional and negative Poisson's ratio thermoplastic polyurethane foams under compressive cyclic loading”, International Journal of Fatigue, v. 29, n. 5, pp. 922-30, 2007. 
[25] TORNABENE, F., FANUZZI, N., BACCIONCHI, M., "A numerical approach based on the GDQ method for the linear static analysis of laminated composite shells subjected to point and line loads", Italy: At Milano; 2017.

[26] MATOS, G.S., MOLINA, J.C., "Shear strength of wood in direction parallel to the grain according to the standards ABNT NBR 7190:1997 and ISO 13910:2005”, Matéria, v. 21, pp. 1069-1079, 2016.

[27] IWAKIRI, S., MATOS, J.L.M., PRATA, J.G. et al., "Characteristics of Glued Laminated Beams Made of Teak Wood (Tectona grandis)", Floresta e Ambiente, v. 21, n. 2, pp. 269-275, 2014.

[28] SEGUNDINHO, P.G.A., ZANGIÁCOMO, A.L., CARREIRA, M.R. et al., "Evaluation of glued laminated timber beams of cedrinho (Erisma uncinatum Warm.)”, Cerne, v. 19, n. 3, pp. 441-449, 2013.

[29] BERTOLINE, C.A.A., TADEU, M.N., BASAGLIA, C.D. et al., "Numerical analysis of glued laminated timber beams reinforced by Vectran fibers", Ambiente Construído, v. 18, pp. 359-373, 2018.

[30] FLORES, E.I.S., FRISWELL, M.I., "Ultrastructural mechanisms of deformation and failure in wood under tension", International Journal of Solids and Structures, v. 50, pp. 2050-2060, 2013.

[31] KAMKE, F.A., LEE, J.N., “Adhesive penetration in wood - A review”, Wood and Fiber Science, v. 39, n. 2, pp. 205-220, 2007.

[32] FIORELLI, J., DIAS, A. A., "Evaluation of Delamination in Wood Pieces of Glulam Beam Reinforced With Glass Fiber”, Revista Matéria, v. 10, n. 2, pp. 241-249, 2005.

[33] EUROPEAN STANDARD. EN 386. Glued Laminated Timber: Performance requirements and minimum production requirements. 2001.

[34] JAPANESE AGRICULTURAL STANDARD. JAS 234: Glued laminated timber. Ministry of Agriculture, Forestry, and Fisheries, Tokyo, Japan, 2003.

\section{ORCID}

Douglas Lamounier Faria

https://orcid.org/0000-0002-5405-8430

Thamirys Andrade Lopes

https://orcid.org/0000-0002-2782-8604

Mario Vanoli Scatolino

https://orcid.org/0000-0002-0412-994X

Julio Soriano

https://orcid.org/0000-0002-3446-532X

José Benedito Guimarães Júnior

https://orcid.org/0000-0002-9066-1069

Lourival Marin Mendes

https://orcid.org/0000-0001-8713-405X 